\title{
A DECADE OF DEMOCRACY IN SOUTH AFRICA AND THE VOCATION OF THE SOUTH AFRICAN AND NIGERIAN THEOLOGIAN AT THE BEGINNING OF A NEW MILLENNIUM
}

\author{
Godwin I Akper \\ Beyers Naudé Centre for Public Theology \\ Stellenbosch University
}

\begin{abstract}
Liberation, it is often argued, is no longer the most helpful metaphor for the present situation in (South) Africa, which needs to capture the complex social and theological challenges ahead. There is a popular view that the new social and political changes brought with them new challenges and responsibilities for theologians in Africa, in general, but South Africa and Nigeria in particular. This essay attempts to examine the South African and Nigerian social and political challenges of the past 10 years. It argues that such challenges should shape, redirect the tasks, contents and methods of theology of African theologians toward "developmental" issues such as poverty, HIV/Aids, wars, public life and public morality, as they seek to address the social and political challenges of the new millennium.
\end{abstract}

Key Concepts: Vocation, liberation, South Africa, Nigeria

\section{Introductory Comments - South Africa}

The theme of the 2004 annual meeting of the Theological Society of South Africa was "The vocation of the theologian after 10 years of democracy in South Africa." This suggests that there is something about the "past" which needs revisiting for the purpose of the possible improvement, adjustment, change of vision and tasks, responsibilities, content and focus of our theology in (South) Africa. ${ }^{1}$ It suggests that, 10 years into democracy, there is a need to rethink our theology so that the "new" challenges and situations may readily be addressed by our "new" theological task and vocations. The appropriate question to ask with reference to the conference theme is: What shape should our theology now take? What should be the task of (South) African theologians 10 years into South African democracy? The situation has arguably changed; "new" challenges have emerged and the political situation has given us a new context for theology. The South African theologian, Takatso Mofokeng (1989:38) observes that the various theological trends that have emerged in South Africa are products of the "intervention of social forces and events". These social forces and events, he argues, "have evidently succeeded to redirect theological thinking or even radically alter theological agendas and priorities and introduce new ones which occupy positions of priority until the next forceful intervention by other social forces and processes" (1989:38). Democracy as a social and political force has intervened in the theological agenda and

I put "South" in brackets because most of what is said of South Africa is applicable to the rest of Africa. I retain "South Africa" where specifically relevant to this country. 
priorities of theologians in South Africa. Hence, there are calls for a rethinking of the way (contextual) theology is practised in South Africa. The question is: What is it that has changed since 1994? Or put differently: Are the "new" challenges really new, demanding distinctively new theological metaphors and idioms capturing the present situation? Should theologians in South Africa embark on extensive search for the most helpful methodologies of dealing with the present (challenges) situation? In any case, what should now be the vocation of the South African theologian?

\section{Introductory Comments - Nigeria}

Five years after flag independence, the Nigerian theologian, Bolaji Idowu (1965), called for a "Nigerian" Church, with its own ministers and theology, capable of addressing the cultural values and religious aspirations of Nigerians. Idowu's proposal does not really stress the need for a Nigerian public theology. ${ }^{2}$ For him, a break from Western ethnocentrism with respect to African values and religious worldview was the most urgent step for African theology to take after 1960, the year of Nigeria's independence from Britain. ${ }^{3}$ If journal and book publications are anything to go by, Nigerian theologians have until recently maintained this rather narrow view of theology advocated by Idowu. The view of many in African theological circles in Nigeria appears to be that with political independence (from Britain), Nigerians are free to theologise, casting "theology into an African construct to give it its African indigeneity", as the Nigerian theologian, Yusufu Turaki (1999:10) puts it. The main interlocutors of African theology in Nigeria since Idowu have mostly been African cultures and African Traditional Religions. The task of theologians in Nigeria has been to provide an interface between Christianity / the Bible and African cultures / Traditional Religions. The works of theologians such as Justin Ukpong (1995, 2002, 2003), Chris Manus (2003) and David Tuesday Adamo (1999) largely reflect Idowu's style of theology. This implies that only one theological paradigm shift has taken place in Nigeria: From Western ethnocentrism to Afrocentrism. Issues of poverty, military dictatorship, the challenges posed by the current democratic process, the scourge of HIV/Aids, communal crises and religious disturbances (mostly from the northern so-called Sharia states in Nigeria), among other things, have not redirected and prioritised theological agendas in the Nigerian context.

2 By public theology I refer to the prophetic witness of the Church and theology - the engagement of theology and the Church in the public sphere ( $c f$. Koopman 2003) - which may include but is not limited to, seeking justice for all, engagement with the government at all levels, evaluation of various civil legislations that often directly or indirectly affects communities of faith and the general well-being of citizens. It may also include issues related to a moral regeneration movement, community development, health issues such as the HIV/Aids pandemic, poverty alleviation programmes and nation building through reconciliation and youth development. All these aspects go a long way to promote human dignity and the welfare of all citizens. An armchair kind of theological vocation is not aggressive enough to bring about any social transformation that will have an impact on the poor - who are the majority in Africa.

At the time Idowu was writing, issues such as Western ethnocentric approach to African Traditional Religions and cultures were relevant. At this point in our history, where we are our own so-called rulers with full access to our own economic resources, it is really of no great value spending so much precious time blaming the Western missionaries and theologians for what was done wrong or left undone (Maluleke 1997a). It is time to engage our African governments and churches for not seriously addressing the issues of poverty, justice and the dignity of our people. While the South African government, churches and theologians are taking up this challenge, it does not seem to be the case in Nigeria. See the volume edited by the Nigerian FU Okafor (1997). What may surprise readers of essays in this volume is that none of the 11 essays in that volume is written by a theologian. This shows how reluctant Nigerian theologians and churches are to engage with the public sphere. Some Roman Catholic theologians are trying, but more needs to be done. 
I propose that the focus of theology in South Africa and Nigeria should be on those "developmental" issues that directly affect the daily lives of Africans. As Maluleke rightly observes, "it is time to own and own up" (1997a). At this time of multiple life crises in Africa the vocation of African theologians should not be to provide an abstract theology, or to embark on an intensive search for what Maluleke (1996) calls a "pro-active premise." Neither is an obsession with colonial missionaries' paternalism crucial at this point (Maluleke 1997a). A theology that is "rooted in [the] real life experience" (Speckman 2001:397) of Africans is most desirable. However, this does not mean that South African and Nigerian theologians should carry on as though nothing has happened ( $c f$. Piet Naudé 2003), but to reflect on the past 10 years and see what challenges the past have left for us to deal with. A point at which to begin may be to reflect on the question raised above: what is it that has changed?

\section{What has Changed?}

There have been notable political and theological changes in the past 10 years of South African and Nigerian democratic history. The question is whether "all" has changed or not. If the change, has meant that Africans are now able to experience the utopia longed for by the liberation struggles, then a triumphant theology - such as those proposed by the Ghanaian Kwame Bediako $(1992,1995)$ and the Gambian born theologian, Lamin Sanneh $(1989,1993)$ - is most appropriate. If this is not the case, then our contextual liberation theologies that were practised long before South Africa and Nigeria saw democracy are still very relevant and must be pursued by theologians from these two countries. Judging from the works of South African theologians, and Nigerian political analysts, it does not look as if everything has changed for the better, although many things have changed. As Maluleke argues, the notion of change is itself contestable, for change, he argues, "almost implies change for better". If this is the case, do we call it change, Maluleke asks, "when things either remain bad or become even worse?" I propose that this should be part of the concerns of South African and Nigerian theologians as they think about the vocation of theologians 10 years into democracy. We as African theologians should not be blinded by the fact that there is democracy in South Africa and Nigeria and so imagine that everything has changed. Therefore, our theology should be redirected to reflect such change. It is misleading to claim that we need a post-democracy theology as if poverty is a legacy exclusively of apartheid (it is also the legacy of successive military regimes in Nigeria) with escalating crime, violence, more cases of war, the prevalence of HIV/Aids, corruption (in the case of Nigeria), and ethnic and religious crises with their various ramifications and hence is a thing of the past.

Politically something has indeed changed in Nigeria and South Africa. However, democracy brought with it daunting challenges that still need to be addressed. The Archbishop of Cape Town, Njongonkulu Ndungane (2003:20) observes that South Africa inherited "from apartheid a legacy of economic and social distress and dysfunction". There is also a certain level of consensus among theologians from South Africa that not much of that legacy has changed since 1994. For Maluleke, not only South Africa is distressed but the whole of Africa (1997a). A look at the past 10 years of democracy in South Africa and Nigeria shows that democracy does not necessarily guarantee or entail economic freedom and equality for all. Certainly it does not mean "all" is indeed well. South Africa and Nigeria were faced with the task of nation building with the advent of democracy in the 1990s. The apartheid legacy created distrust, loss of human dignity and worst of all division on the basis of race among South African populations. The chain of military 
dictatorships left Nigeria with similar social ills. South Africa was to build a just and new South Africa for all races. Nigeria was faced with the task of reconciling the different ethnic groups especially the North and South divide, on the one hand, and Muslims and Christians on the other. Nigeria has not experienced since the civil war (1966-169) such violence and war that has killed thousands of people as during the past 10 years. Just a few weeks ago a state of emergency (June 2004) was declared in one of the central states in Nigeria in a desperate attempt to end the four years of communal crises in that region. The politically motivated war between supporters of the ruling People's Democratic Party and the main opposition, the All Nigerian Peoples Party, left several hundreds of people dead the majority of whom were not even party loyalists. Most of the militia youths employed for this evil activity are jobless and - regrettable to admit - confessing Christians from poor backgrounds. Again poverty has played a role in the present political, religious and communal crises in Nigeria and this may be true of other parts of Africa (cf. Maluleke 1997a). The biggest challenges also included the problem of economic inequality as evident in the gap between the rich and the poor. In these areas there is still a lot to be done in both countries. If anything, especially for Nigeria, things have become worse $!^{4}$

The government of former President Nelson Mandela thought that there could be "no future without forgiveness" (Tutu 1999). The government also believed that there could be no true forgiveness if the truth is not told. Hence, the Truth and Reconciliation Commission (TRC) was the instrument charged with the responsibility of looking at past injustices with the view to promoting reconciliation and transformation for the future of the new South Africa. The success of this Commission is contestable. While the former TRC secretary, Charles Villa-Vicencio (2001:242) speaks as though the TRC accomplished its mission, many South Africans do not share Villa-Vicenio's viewpoint. Maluleke (1997b), Radikobo Ntsimane (2000) and Piet Naudé (2003), for example, think the TRC process and its concept of "forgiveness" without what Naudé calls "restorative justice" (2003:408) is not capable of effecting the kind of reconciliation that South Africa desires. ${ }^{5}$ For Ntsimane (2000), the TRC's "forgiveness" is at best a "mirage". 6

When President Obansanjo assumed power in 1999, he adopted former president Nelson Mandela's TRC model as a "miracle" (Botman 1996:39 in Maluleke 1997b:326) that could work out a process of reconciliation for Nigerians. Unlike the South African TRC, a retired Supreme Court justice, Justice Chukwudifu Akume Oputa headed the Nigerian Truth Commission; and a Roman Catholic priest, Fr Mathew Kukah was its scribe. The Nigerian political scientist, Omo Omoruyi describes the task of the Nigerian Truth Commission as follows: "The end of the Commission's effort is not only to lead to reconciliation among the Nigerian peoples but in large measure to unearth the truth about

4 Commenting on the situation from his context, Archbishop Ndungane remarks that "political liberation has been realized. We now face the enormous challenge of restructuring the economy in such a manner that the well being of all the citizens will be provided for" (2003:21). Speckman notes that poverty is indeed escalating in South Africa (2001:401).

5 Archbishop Ndungane also argues that the "limited mandate and duration" of the TRC "did not allow the commission to dig deep enough into our past and come up with recommendations that would set the tone for lasting peace" (2003:19). Like Naudé (2003:408), Ndungane believes that restorative justice is needed in order to attain the lasting peace that is needed in South Africa.

6 For Ntsimane, a person is a victim of a mirage if he or she sees something that is not really there. According to him, the TRC's process was defective; therefore, the Commission is mistakenly when it refers to the forgiveness of the perpetrators of human rights violation by their victims. 
past injustices. It is common sense that there cannot be reconciliation among peoples with out truth.",

None of the former dictators appeared before this Commission. They instead sought and received court injunctions restraining the Federal Government from implementing the recommendations of the Commission and also restraining the Commission from compelling them to appear before it. The court ruled in their favour, arguing that the Commission lacked constitutional backing. Therefore, for Nigeria, the truth was never told, hence there is no reconciliation possible yet. It turned out that only the poor and "insignificant" ordinary people appeared before the Nigerian Truth Commission led by Oputa. The irony of the whole thing is that the perpetrators were the rich former military dictators and not the ordinary Nigerians who appeared before the Commission, probably because they had no "economic power" to refuse to appear. With this kind of system in place, the poor in Nigeria can never dream of any other justice than a mob or jungle type of justice. This explains why there has been a breakdown of law and order in Nigeria in the past 10 years. There is no doubt that poverty remains the greatest challenge to the nascent Nigerian and South African democracies. What about theology? Has there been any change in this sphere?

As Maluleke points out (2001:388), those theologians who take the end of the Cold War and apartheid as their theological starting points have made calls for different theological idioms. Charles Villa-Vicencio, even before 1994, thought that liberation theology would soon lose its relevance. Hence he argued for a transformative kind of theology such as his theology of reconstruction (1992). The Kenyan Jesse Mugambi (1995) also argued for a theology of reconstruction as the most helpful theological metaphor for the new world order. Indeed, those who viewed the task of Black theology or maybe contextual theologies as merely being to fight apartheid and its policies obviously could not see any future for contextual theologies like the Black theology of liberation after 1994. In fact, there has been some kind of "theological silence" (Maluleke 2001:372; Speckman 2001:391-396) between 1986 and 2000 (Maluleke 2001:372). Speckman (2001:392) argues that contextual theology, its various manifestations notwithstanding, "is still based on a response to the past political context, therefore, resistant." This led him to the conclusion that contextual theology in South Africa has lost its relevance. His concern is that the theological agenda of contextual theology at present is not clear in its South African context. Contextual theology, he argues, seems to be suffering from an identity crisis. Russel Botman (2001:116-130) also alludes to this crisis.

However, to lay down a hoe does not mean one has stopped working goes the African proverb (cited in Mbiti 2003). Hence, just because there has been some silence in certain areas does not mean that contextual theologians are no longer speaking. The presence of African women's voices within African theology and the Ecumenical Association of Third World Theologians (EATWOT), and the emergence of "critical" contextual hermeneutics and public theology, seeking to address theologically the various concerns of the poor and the marginalised communities of faith in South Africa and Africa suggest that not all is silent. Certainly, not all contextual theology is suffering from identity crisis though there is no doubt that there is an identity crisis in some forms of contextual theology, as Speckman, Botman and Maluleke, among others, have argued (see their articles in the volume edited by Speckman \& Kaufman 2001). If journal publications are anything to go by, contextual theologies and hermeneutics - such as African Women's Theology and theological projects

See www.nigerdeltacongress.com/articles/refocusing_the_oputa_comission_1.htm 
such as those of the Institute for the Study of the Bible (ISB) associated with Gerald O West at the University of KwaZulu-Natal and Inculturation theology associated with the Nigerians Justin Ukpong and Chris Manus - are eloquent enough to show that not all contextual theology (and hermeneutics) is lost, or suffering from identity crises.

I share the concern of Maluleke (1997a, 1997b \& 2001) and Speckman (2001) that some of those proposals are not capable of effecting the kind of change that is needed at present. They either turn out to be too abstract or are simply laments about the condition of Africans without necessarily suggesting ways that could change the present situation. I do not think that this is the kind of contextual theology that South Africa and Nigeria need in this century.

The present challenges deserve a clearer theological focus and agenda than what is obtainable at present. In the next section I will make my own proposals with respect to what I think should be the theological tasks and focus (vocation) of Nigerian and South African theologians at the beginning of a new millennium. In this section, however, I limit myself to what theological changes have taken place so far. I contend that what has really changed is theological idioms and metaphors and not really the contents of theology. Certainly, the apparent silence mentioned earlier does not in itself indicate that change has occurred. In other words, I allude to the position of Maluleke (2001) that post-colonial theologies as well as post-Cold War and post-apartheid theologies were all anticipated by liberation theology. Therefore, reconstruction theology, post Cold War, post-apartheid or whatever other "post"-theologies that have emerged in the past 10 years did not offer anything completely new. They are rather different expressions of age-old theologies masquerading as "post theologies". In fact hermeneutics has always been contextual ( $c f$. Tracy 1987; West 1991, 1992a, 1992b, 1997, 2002a, 2002b; Banana 1993; Punt 1999a, $1999 \mathrm{~b}$ and Jonker 2000). Hence, it does not really matter whether one calls the various forms of hermeneutics that emerged in the past 10 years contextual hermeneutics or not. What matters is whether they are able to change the situation of the poor and marginalised or not. My argument is that there has not been any real theological change over the past 10 years. If so, we must prioritise our theological agenda to suit the present challenges. The nature of the present challenges should define our vocation at the beginning of a new millennium.

\section{The Vocation of the Theologian in this Millennium}

The poor (who are also the marginalised) are still with us in South Africa and Nigeria, 10 years of democracy notwithstanding. Since the poor are more numerous than the privileged few who are rich and powerful, if our theologies are to be relevant, then it should seek to address the concerns and issues arising from the situation of the poor. Violence and crimes, wars, HIV/Aids, religious disturbances, genocides and the other social ills prevalent in South Africa and Nigeria arguably have their root causes in poverty. I propose that the vocation of theologians in the new millennium should be to find ways of liberating Africans from the captivity of poverty that imprison them. I do not think that we need a new theological starting point to do this, just because we are 10 years into democracy. Democracy, globalisation and all the other "big" words have not been able to alleviate the poverty that is threatening the lives of Africans, be they in South Africa, Nigeria or any other place in Sub-Saharan Africa. Instead these global ideologies may further impoverish Africa (Maluleke 2001). These global processes should not divert our attention away from the real-life issues that affect us in Africa today. We should not so much be concerned with the name that we give to our theologies after 2004 but with the challenges before us. 
Whether contextual theology, African theology, Black theology, Women's theology, Inculturation theology, Reconstruction theology, Reformed theology or whatever else, the theological agenda should be to liberate the poor.

The South African theologian Nico Koopman suggests that the view that God is the God of the suffering, the poor is not the product of Liberation theology but of Scripture (2002:252). Therefore, if our theology in Africa in this millennium is to be biblical, then we must rise and go beyond the task of merely signing up to stand with the poor, to actually addressing the concerns of, and matters arising from, the situation of the poor. The Belhar Confession (a confession of the Uniting Reformed Church) calls on the church to follow God in "that He brings justice to the oppressed and gives bread to the hungry; that He frees the prisoner and restores sight to the blind; that He supports the downtrodden, protects the stranger..." (Belhar Confession 1986, www.rca.org/aboutus/beliefs/belhar.php). To respond to the call of the Belhar Confession, theologians should take up the prophetic task of bringing justice, peace, an alleviation of poverty and reconciliation between the poor, the rich and God ( $c f$. Mofokeng 1983).

The vocation of theologians should also be to see and interpret the signs of the times (Albert Nolan 1988) and to respond appropriately. The Kairos theologians' challenge to the Church in the second half of 1980s was a move in the right direction. Although the Kairos theologians themselves failed to interpret the signs of the times after 1990 - a mistake on their part which contributed to the failure of Kairos theology once apartheid was abolished, ${ }^{8}$ - they act as eye openers to theologians (especially Nigerian theologians of the so-called conservative type) to see and interpret the society within which the church finds herself in order to be able to speak prophetically. If John Calvin's legacy is anything to go by, I would maintain that no one else is better equipped to see and interpret the signs of the times in Africa than theologians. The Scriptures provides the spectacles with which we see what God is doing in South Africa and Nigeria (Nolan 1988). While I accept the view that an

\footnotetext{
For brief background information on Kairos theology, see Botman (2001:117-118). Botman argues that the dead end of Kairos theology and its complete silence for the past 10 years is due to two factors: Its internal theological constraints and the sociological, political and legal nature of the Kairos Document itself. It lacked a Christological orientation that would have clarified matters that the "will of God is not revealed anywhere else, but in Christ" (2001:119). Also, Botman maintains, the Kairos Document's insistence that the then conflict in South Africa was between the oppressor and the oppressed - hence, creating the impression that the oppressor and the oppressed represented "irreconcilable causes or interests" - did not help matters. Once the African National Congress and the Communist Party adopted the sunset clause, setting the stage for negotiations with the then "enemy", as the Kairos Document puts it, the Kairos Document itself became irrelevant to some extent (Botman 2001:119-120).

Botman also blames the demise of Kairos theology on the change in the nature of the state. The postapartheid state is secular. Although its constitution has a supposedly religious clause "Nkosi, Sikelela I'Africa" (God bless Africa), it does not subscribe to any religion, thereby remaining distinctively secular (Botman 2001:120). According to Botman, this created an identity crisis in formulating a clear-cut ChurchState theology.

I would say the same of the Nigerian situation. The Nigerian National Pledge ends with the clause "so help me God". The problem is the God in view. Because of this problem, Nigeria does not adopt any particular religion in its constitution. Its constitution remains secular. Any version of the South African Kairos Document of the 1980s therefore cannot be exported to Nigeria without facing similar challenges, if not failures. However, its general call to churches to see and interpret the crises that were coming in South Africa during the difficult days of the disintegration and dismantling of apartheid is commendable. Perhaps by learning from the past experience of the Kairos Document, South African and Nigerian theologians could come up with a new Kairos Document with a longer vision about the crisis of poverty that is threatening the foundation of the Christian faith and Africa now and in the years to come.
} 
interdisciplinary approach to contemporary issues in Africa is essential, ${ }^{9} \mathrm{I}$ also contend that public issues should not be left in the hands of political, economic and social analysts only. ${ }^{10}$

The task of seeing and interpreting the signs of the times involves seeing in the same way. In his essay in honour of John De Gruchy, Dirkie Smit remarks that "one of the painful effects of Apartheid was that South Africans did not see in the same way" (2002:272). I propose that South African and Nigerian theologians should attempt to see in the same way. If South African theologians are able to see the need for prophetic witness in Africa, then Nigerian theologians should also be able to see this. It may well be true that, as far as prophetic witness is concerned, South African theologians have "sharper eyes". It may also be true that Nigerian theologians have done more work in the area of the study of African Religions ( $c f$. Maluleke 1998, where he expresses his frustration over the lack of South African theologians doing African theology with him). South African and Nigerian theologians should therefore seek to do theology in the spirit of $u b u n t u^{11}$ in order to see in the same way (I make this proposal while still agreeing with Maluleke, 2001:369). It is not so much a case that we must agree on everything that we say or do, but that we should all be able to see what challenges affect us in Africa and how best to respond to them. It is a question of prioritising.

The vocation of the theologian also involves making the voice of the poor heard. Arguing for a swift transformation in the mode of public theology as a response to what he sees as the unfolding process of democratisation in South Africa since 1994, Koopman (2003a:13) insists that "the voices of the marginalized in the society should be heard in the public theological discourse". Maluleke (2001:374) argues that our theological agenda should not be drawn from "some knee-jerk reaction to the end of the cold-war". His reason is that "while the 1990's have been defined in terms of change, the majority of Black Africans have not experienced any positive change, instead many have experienced a worsening of their conditions". I would argue that the same applies to Nigerian Africans. Many average Nigerians think that the colonists and missionaries meant well and did more

9 Such an approach is evident in the essays in the volume edited by Philippe Denis (2000) and the volume on Building a Human Rights Culture edited by Karin Sporre and Russel Botman (2003).

10 Writing on Karl Barth in South Africa, and especially commenting on the Protestant churches' response to the conviction that "God is the God of the poor", Dirkie Smit (1988:17) remarks that "many people, including ministers of religion, find this hard to accept" for many reasons such as: "The Bible and the Christian tradition has simply never taught this option for the poor"; that this "claim fundamentally contradicts their understanding of the obvious universality of God's love and actions according to the Bible...", or that "the idea of partiality" implicit in the conviction "is alien to their own moral convictions and not applicable to God", among other reasons ( $c f$. Koopman 2003a).

This also applies to Protestant churches in Nigeria. Some Nigerian theologians in Evangelical or Protestant churches believe that the public life belongs to the "public". Therefore the church should not be involved in public affairs. This viewpoint gave other religions the upper hand in influencing government policy issues. The rise of the Sharia controversy arose partly because of the church's distance from public life in Nigeria.

11 For Desmond Tutu, ubuntu refers to "that worldview which teaches that to be human is to be a fellow-human being". Humanity is not defined by the modernistic formula: I think, therefore I am. But in terms of the formula: "I belong therefore I am" ubuntu entails "a life of reciprocity, communion, care, responsibility and hospitality" (Koopman 2003a:18 cf. 2003b:204). My appeal to the ubuntu philosophy to describe the vocation of South African and Nigerian theologians coincides with Koopman's reciprocity ethos: His conviction is that "ethos of reciprocity paves the way for the strengthening of civil society where the importance of the contribution of every member and group of society is recognized with regard to the emphasis on reciprocity, the potential of ubuntu for the strengthening of civil society in Africa, and specifically South Africa might be explored" (2003a:18). 
for Nigerians than what they are seeing in Nigerian politicians today (see an incisive historical overview by Ayodeji Olukoju (1997:12-40).

The point is that the poor are still poor if not poorer; human rights abuses are still rampant, the scourges of ethnic wars, violence, HIV/Aids and so on are still issues that our people have to live with daily. Those who live under such conditions cannot help but keep silence; even if others do not silence them, they are silenced by their conditions. West has devoted his time since 1991 to make the voice of the poor heard in theological discourse. A number of his publications indicate this (see, for example, 1991a, 1991b, 1992a, 1992b, 1997, 1999a \& b, 2001, 2002a). I long to see that day when the poor and marginalised whom West works with could speak for themselves in theological discourse.

I share Maluleke's sentiment when he notes that African theologians such as Sanneh and Bediako write as if all is well in Africa. As he puts it: "Kwame Bediako and Lamin Sanneh are writing about the need for Christian theology to let go of the assumption that Christianity is foreign to Africa; but they are doing so almost in total disregard of the voices of various liberation and feminist theologies on the continent". He subjects Mugambi's proposal on reconstruction to the same charge (2001:374-375). I argue that the poor are still silenced. Therefore, in the new millennium, the task of theologians should not be to crown the past 10 years with theological metaphors of praise, but to seek ways by which the poor could contribute to theological discourse in Africa.

The Nigerian story - and this may be applicable to the rest of Africa - suggests that there is a need for theologians to address the issue of worship, of congregational life and of the commitment of many believers. If Christians can be raised as a militia to destroy other Christians and churches in the name of party politics or ethnicity, then it means there is something severely wrong with Christian life in Nigeria. Therefore, the vocation of theologians should include moral regeneration activities that could build a Nigerian society that actually practice Christian love - which involves care, and respect for the lives of fellow human beings. In Speckman's (2001) view, commitment to moral regeneration would be a developmental project as it involves developing the "whole" person.

What I have proposed here is not intended to be the vocation of the South African and Nigerian theologians in this millennium. My proposals are just some cursory suggestions to complement what others have suggested. In the spirit of ubuntu, I hope to learn more from my colleagues.

\section{Conclusion}

I have tried in this essay to show that the context within which South African and Nigerian theologians undertake their vocation suggests that, while things may have changed politically, the majority of South Africans and Nigerians have not yet experienced any positive change. In the case of Nigeria, the process of political change is still incomplete. Therefore, our vocation in this millennium should not be derived mainly from the existence of a post-apartheid and post-military democratic dispensation. Instead, the situation of the poor and the challenges that poverty have posed to us should compel us to prioritise our theological agendas to address the issue of poverty and all its ramifications. 


\section{BIBLIOGRAPHY}

Adamo, DT 1999. Cultural Hermeneutics. In: Sugirtharajah, RS (ed.): Vernacular Hermeneutics. Sheffield: Sheffield Academic Press, 66-90.

Banana, CS 1993. The Case for a New Bible. In: Cox, LJ, Mukonyora, I \& Verstraelen, FJ (eds.): "Rewriting" the Bible: the Real Issues. Gweru, Zimbabwe: Mambo Press, 17-32.

Bediako, K 1992. Theology and Identity: The Impact of Culture upon Christian Thought in the Second Century and Modern Africa. Oxford: Regnum.

Bediako, K 1995. Christianity in Africa: The Renewal of Non-Western Religions. Edinburgh: Edinburgh University Press.

Botman, RH 2001. The Crisis in Contextual Theologies: A Way Ahead? In: Kaufmann, LT \& Speckman, MT (eds.): Towards an Agenda for Contextual Theology: Essays in and Honour of Albert Nolan. Pietermaritzburg: Cluster Publications, 117-129.

Botman, RH \& Sporre, K (eds.) 2003. Building a Human Rights Culture. South African and Swedish Perspectives. Falun, Sweden: Stralins.

Denis, P (ed.) 2000. Orality, Memory and the Past: Listening to the Voices of Black Clergy under Colonialism and Apartheid. Pietermaritzburg: Cluster Publications.

Frostin, Per 1988. Liberation Theology in Tanzania and South Africa A First World Interpretation. Lund: Lund University Press.

Idowu, B 1965. Towards an Indigenous Church. London: SPCK.

Jonker, L 2000. The Influence of Social Transformation on the interpretation of the Bible: A Methodological Reflections. Scriptura, 75, 1-15.

Koopman, N. 2003a. Some Comments on Public Theology Today. Journal of Theology for Southern Africa, 117, 3-19.

Koopman, N 2003b. Trinitarian Anthropology, Ubuntu and Human Rights. In: Botman, R \& Sporre, K (eds.): Building a Human Rights Culture: South African and Swedish Perspectives. Falun, Sweden: Stralins, 194-205.

Manus, UC 2003. Intercultural Hermeneutics in Africa Nairobi, Kenya: Action Publishers.

Maluleke, TS 1996. Black and African Theologies in the New World Order; A Time to Drink from Our Own Wells. Journal of Theology for Southern Africa, 96, 3-19.

Maluleke, TS 1997a. Christianity in a Distressed Africa: A Time to Own and Own Up. Missionalia, 26(3), 324-340.

Maluleke, TS 1997b. "Dealing Lightly with the Wound of my People?" The TRC Process in Theological Perspective. Missionalia, 25:3, 324-343.

Maluleke, TS 1998. Africa Traditional Religions in Christian Mission and Scholarship: Reopening the debate that never started. Journal of Religion and Theology, 5(2), 121-137.

Maluleke, TS 2000. A Historical Quest for a Black Presence that "Walks". In: Denis, P (ed.): Orality, Memory and the Past. Listening to the Voices of Black Clergy under Colonialism and Apartheid. Pietermaritzburg: Cluster Publications, 229-250.

Maluleke, TS 2001. Theology in (South) Africa: How the Future has changed. In: Kaufmann, LT \& Speckman, MT (eds.): Towards an Agenda for Contextual Theology: Essays in Honour of Albert Nolan. Pietermaritzburg: Cluster Publications, 364-389. 
Mbiti, JS Some Resting Points in African Theology. Unpublished essay read at African Theologies in Transformation Conference, University of the Western Cape, 3 June 2003.

Mofokeng, T 1983. The Crucified Among the Crossbearers: Toward a Black Christology. Kampen: Kok.

Mofokeng, T 1989. The Cross in Search of True Humanity: Theological Challenges facing South Africa. Journal of Black Theology in South Africa, 38-50.

Mugambi, JNK 1995. From Liberation to Reconstruction: African Christian Theology After the Cold War. Nairobi: East African Educational Publishers.

Ndugane, N 2003. A World with a Human Face: A Voice from Africa. Geneva: WCC Publications.

Nolan, A 1988. God in South Africa: The Challenge of the Gospel. Cape Town: David Philip.

Naudé, Piet 2003. Sola Gratia and Restorative Justice. Scriptura, 84(2), 402-409.

Okafor, FU (ed.) 1997. New Strategies for Curbing Ethnic \& Religious Conflicts in Nigeria. Enugu: Fourth Dimension Publishing.

Olukoju, A 1997. Nigeria: A Historical Review. In: Okafor, F.U. (ed.): New Strategies for Curbing Ethnic \& Religious Conflicts in Nigeria. Enugu: Fourth Dimension Publishing Co., 12-40.

Punt, J 1999a. Reading the Bible in Africa: Accounting for Some Trends. Scriptura, 70, 1-11.

Punt, J 1999b. Reading the Bible in Africa, Accounting for Some Trends: Prolegomena for further discussion. Scriptura, 71, 313-329.

Sanneh, L 1989. Translating the Message: The Missionary Impact on Culture. Maryknoll, New York: Orbis Books.

Sanneh, L 1993. Encountering the West: Christianity and the Global Cultural Process. Maryknoll, New York: Orbis Books.

Smit, D 1988. Paradigms of Radical Grace. In: Charles Villa-Vicencio. On Reading Karl Barth in South Africa. Grand Rapids, Eerdmans, 17-44.

Smit, D 2002. Seeing Things Differently. In: Holness, Lyn \& Wustenburg, Rolf (eds.): Theology in Dialogue the Impact of Arts, Humanities, and Science on Contemporary Religious Thought: Essays in honour of John De Gruchy. Grand Rapids / Cambridge / Cape Town: Eerdmans / Cambridge University Press / David Philip, 271-289.

Speckman, MT 2001. For Nolan's Sake, Let's Move On: A Plea for a Developmental Dimension in Contextual Theology. In: Kaufmann, LT \& Speckman, MT (eds.): Towards an Agenda for Contextual Theology. Essays in Honour of Albert Nolan. Pietermaritzburg: Cluster Publications, 390-401.

Tracy, D 1987. Plurality and Ambiguity: Hermeneutics, Religion, Hope. San Francisco: Harper and Row.

Turaki, Y 1999. Christianity and African Gods: A Method in Theology. Potchefstroom: IRS, PU for CHE.

Tutu, D 1999. No Future Without Forgiveness. Parttown, Auckland, New South Wales: Random House.

Ukpong, JS 1995. Reading the Bible with African Eyes: Inculturation and Hermeneutics. JTSA, 91, 3-14. 
Ukpong, JS 2000. Development of Biblical Interpretation in Africa: Historical and Hermeneutical Directions. In: Dube, M \& West, GO (eds.) The Bible in Africa: Transactions, Trajectories, and Trends. Boston, Leiden, Koln: Brill, 11-28.

Ukpong, JS 2002. Reading the Bible in a Global Village: Issues and Challenges from African Readings. In: Ukpong, JS: Reading the Bible in the Global Village: Cape Town: SBL, 9-39.

Ukpong, JS 2003. Biblical Interpretation in Africa: Transcending the Boundaries of Inculturation and Liberation. Journal of Inculturation Theology, 5(2), 105-122.

Villa-Vicencio, C 1992. A Theology of Reconstruction. Cape Town: David Philip.

West, GO 1991a. Biblical Hermeneutics of Liberation: Modes of Reading the Bible in the South African Context. Pietermaritzburg: Cluster Publications.

West, GO 1991b. The Relationship between the Different Modes of Reading (the Bible) and the Ordinary Reader. Scriptura, 9, 87-110.

West, GO 1992a. Recovering the Suppressed Past and Reconstructing the Future: Historical Consciousness, Biblical and Theological Liberation Hermeneutics. Unpublished Paper. Human Sciences Research Council, Centre for Research Methodology, Pretoria.

West, GO 1992b. Some Parameters of the Hermeneutical Debate in the South African Context. JTSA, 80, 3-13.

West, GO 1997. On the Eve of African Biblical Scholarship Trajectories and Trends. JTSA, 99, 99-115.

West, GO 1999a. The Academy of the Poor: Toward a Dialogical Reading of the Bible. Sheffield: Sheffield Academic Press.

West, GO 1999b. Local is Lekker, but Ubuntu is Best: Indigenous Reading Resources from a South African Perspective. In: Sugirtharajah, RS (ed.): Vernacular Hermeneutics. Sheffield: Sheffield Academic Press, 37-51.

West, GO 2001. Contextual Bible Study in South Africa: A Resource for Reclaiming Land, Dignity and Identity. In: Kaufmann, LT \& Speckman, MT (eds.): Towards an Agenda for Contextual Theology: Essays in Honour of Albert Nolan. Pietermaritzburg: Cluster Publications, 169-184.

West, GO 2002. The Bible as a Bola among the Foundation of African Biblical Apprehensions. JTSA, 112, 23-37. 